Volume 6, Issue 6, November - December 2019, pp. 9-22, Article ID: JOM_06_06_002

Available online at http://www.iaeme.com/JOM/issues.asp?JType $=J O M \& V T y p e=6 \& I T y p e=6$

Journal Impact Factor (2019): 5.3165 (Calculated by GISI) www.jifactor.com

ISSN Print: 2347-3940 and ISSN Online: 2347-3959

DOI: 10.34218/JOM.6.6.2019.002

C IAEME Publication

\title{
UNDERSTANDING PURCHASE INTENTIONS OF PRE OWNED CLOTHING IN INDIA
}

\author{
Anupam Kapoor \\ PhD Research Scholar, National Institute of Fashion Technology, New Delhi, India
}

Ajit Kumar Khare

Professor, National Institute of Fashion Technology, Bhopal, India

\begin{abstract}
The environmental issue is considered in the Post-consumer textile waste, including garments discarded by the original owner. Fashion industry is known for its unsustainable way of working due to over-production and overconsumption. The best solution to be sustainable is collaborative consumption and garment life extension. Environmental activist hugely emphasize on consumption of second hand garments. Therefore it is important to pay attention to the factors that affect the purchase of second-hand clothing since it is not a simple form of mercantilism. The purpose of this study is to create new knowledge by identifying factors that influence the customer in consuming second-hand apparel in the area of second-hand products consumption and customer intentions.

In order to fulfil the research purpose, a quantitative research approach and cross sectional research design were adopted. Questionnaires were designed using Google survey tool and through this method 160 questionnaires were collected from respondents. SPSS was used to perform for descriptive statistics, reliability analysis, bivariate correlation, single item measurement and multiple regression analysis.

5 factors namely, functionality, convenience, perceived hygiene, personal attitude and social factor were derived from 24 variables. The five factors explained a variance of $78 \%$ to the concept of purchase intension of second hand clothing.

Finding out an overall understanding about the second-hand product consumption will be interesting for the marketers, customers and socio environmental activists working towards sustainability in the fashion industry.
\end{abstract}

Keywords: Second hand apparel, Sustainable fashion, reuse, second hand market, Indian consumer.

Cite this Article: Anupam Kapoor and Ajit Kumar Khare, Understanding Purchase Intentions of PRE Owned Clothing in India, Journal of Management (JOM), 6 (6), 2019, pp. 9-22.

http://www.iaeme.com/JOM/issues.asp?JType=JOM\&VType=6\&IType=6 


\section{INTRODUCTION}

Amongst the shopaholics "Shop till you drop" is the favourite saying, especially for those who love shopping for apparel and related products. Confessions of shopaholics are that they cannot seem to break their habit for making impulsive purchases. Fast fashion retailing, globalization of fashion and rapid growth in Indian economy is leading consumers towards an increased rate of purchasing (McAfee et al., 2004). Second-hand products can be defined as the reuse of an old product while maintaining its original functionality (WRAP, 2013, p. 7). India has long traditions of pre-owned clothing consumption within the family that is deeply rooted in the society. Second-hand clothing shoppers appear to be motivated by several factors. According to Guiot and Roux (2010), fair price, ethics, environmental concerns, and recreational benefits have enabled the proliferation of second-hand markets. Fashion authenticity and vintage uniqueness are other characteristics appealing to today's consumers (Palmer \& Clark, 2005). Stroeker (1995) identified price, uniqueness, desire to try on clothes, environmental consumerism, and hobbies as reasons for purchasing from second hand retail sources.

\subsection{Why should One Consume Second Hand Clothing?}

The environment benefits range for the second-hand clothing industry from fewer carbon discharges to save water and reduce waste. Figure 1 explain the system thinking diagram for the clothing consumption cycle and the stages that have an impact on the environment.

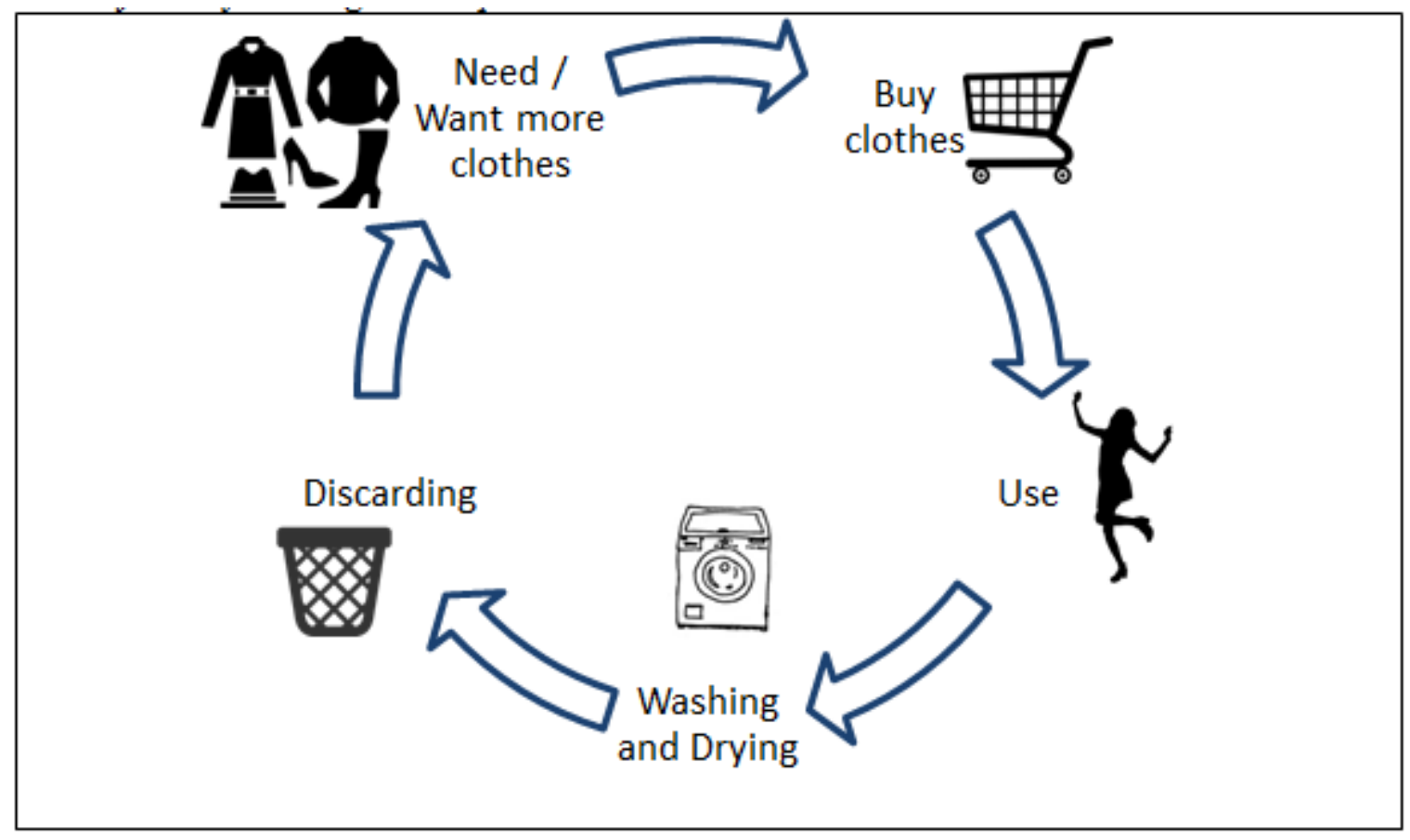

Figure 1 System of clothing consumption 


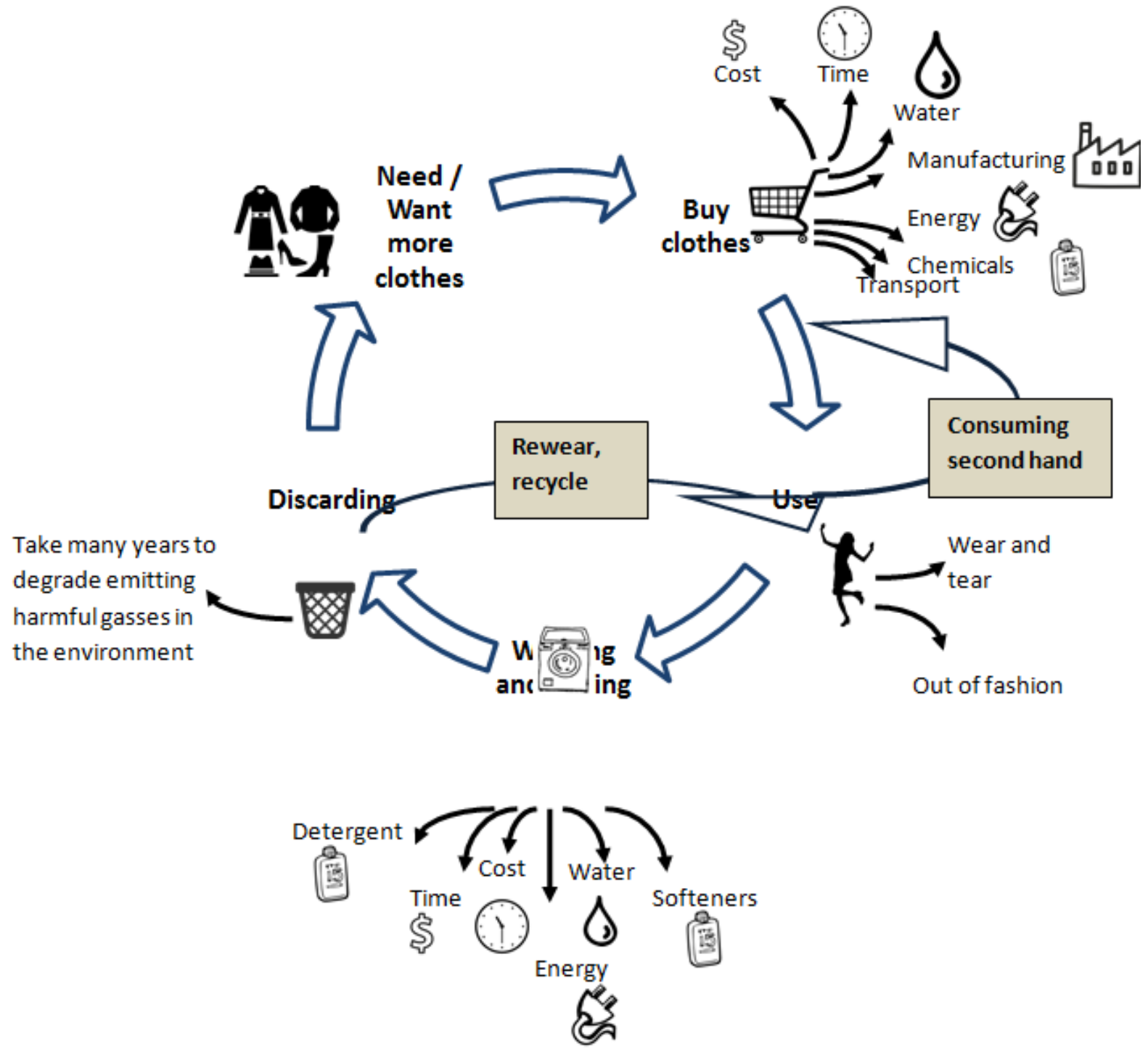

Figure 2: Identifying problems and solutions in the system of clothing consumption

\subsection{The Manufacturing Stage}

For establising the impact of garments on the environment, this section has taken the example of a simple cotton t-shirt assesing the impact cotton has from the fibre and fabric processing, spinning and knitting, fabric finishing all the way up to the use phase and the cut make trim phase as cotton is one of the favourite fabrics consumed.

The total area dedicated to cotton growing (30 to 35 million hectares) has not changed significantly since the 1950 s but the output has nearly tripled during the same period. This increase in output is largely due to pesticides and fertilizers used in conventional cotton production (2)causing a range of environmental and social impacts.

Another huge impact conventional cotton farming has on the environment is its impact on the earth's water balance."Water consumption - especially the extensive use of water in cotton crop cultivation - can also be a major environmental issue as seen dramatically in the Aral Sea region." (5)The "spinning, weaving and knitting" stages use a lot of energy, produce solid waste and generate dust and noise and also involve the use of lubricants and oils to strengthen and protect the fibres from the stresses of processing. (7) 
These substances are removed before the next production phase which involves a huge amount of water and the use of more chemicals, like pentachlorophenol, a rot-proofing agent added to cotton fabric to protect it in transport and storag. (8)The fabric finishing stages prepare the fabric to be dyed and/or printed."Finishing is the chief cause of environmental impacts in the production phase, using significant quantities of water, energy and chemicals and producing substantial amounts of effluent". (9)Chemicals used for finishing contain, amongst many others, heavy metals like copper, chromium and cobalt which are known hormone disrupters, and formaldehyde, a chemical.

In order to achieve white fabrics, it is necessary to bleach fibres as natural fibres have an off white colour. Bleaching is also used prior to dying to achieve better colour results.After bleaching the fabrics or fibres are dyed. Before 1956, the majority of clothes were dyed using natural dyes, "..but technological changes, industrialization and population growth brought about a rapid increase in textile production.." (13) Due to the amount of land needed to grow the dyes, natural dyes could no longer fulfill the demands. Modern dyes are based on petrochemicals, a non renewable resource and there are many risks to human health and the environment from modern dyes. After dying the fabrics it releaes polluted waste which is a great danger to the environment, as the global textile industry discharges 40,000 to 50,000 tons of dye into rivers etc annuall. (14)

Now the fabric is ready to be made into garments and the next stage is the cut - make- trim stage where the impacts are mainly social and worker related. Due to the globalised supply chains we have in the fashion industry an "..average T-shirt travels the equivalent distance of once around the globe during its production" (15) due to transport between different processors. From cotton field to textile mill to the garment factory, each stage adds to the carbon emissions.

\subsection{The Use Phase}

The use phase, meaning the phase when the garment finally reaches the consumer, is a phase with a high impact on the environment. Most environmental impact comes from laundering and not from growing, processing and producing of the fabric or disposing of it at the end of its life. (16)

"..the major part of environmental impact in the lifecycle of a blouse arises from the consumer use phase..", "as much as 82 per cent of energy use, 66 per cent of solid waste, over half of the emissions to air and large quantities of waterborne effluents are amassed during washing and drying." (17)

There are different ways of disposing of old unwanted garments with different impacts on the environment. More environment friendly than new clothing, second-hand has less carbon foot prints. It does not consume energy required for manufacturing and transportation and, therefore, does not produce the carbon dioxide associated with production, transport, care, or disposal (Allwood et al., 2006).

\section{LITERATURE REVIEW}

Multiple second-hand retail formats have emerged due to increased consumer interest in resale apparel. These formats include vintage selling, charity/thrift outlets, consignment shops, retro outlets, garage sales, swap events, flea markets, car-boot sales, dress agencies, auction clearances events, antique fairs, and a jumble of miscellaneous sales (Gregson \& Crewe, 2003; Guiot \& Roux, 2010; Williams \& Paddock; 2003).

Second-hand clothing comprises of a global market of business and consumption that has a long but changing history. The second hand clothing trade has more than doubled worldwide between 1991 and 2004 both in terms of expansion in economic power and global scope. This has happen mainly due to a sudden liberalization of many third-world economies and following 
the sudden rise in demand from former Eastern Bloc countries in the early 1990s (Hansen and Tranberg, 2011). In the twenty-first century, buying second hand clothing is looked upon and makes up a specialty or niche segment in much of the West, whereas in the developing countries, an important clothing source for them is second hand clothing imported from the West. Both, in terms of both volume and value, the US is the world's largest exporter, followed by the United Kingdom, Germany, and the Netherlands in 20014. The countries of sub-Saharan Africa are the world's largest second hand-clothing importers, receiving close to 26 percent of total world exports in 2014 (Rodgers, 2015).

The popularity and wide access of internet has further fuelled to the growth of second handclothing market, especially its designer-trading aspect. It has given rise to many auction sites, and specific Web-based sites that have expanded the previously worn clothing business vastly (Noon, 2011). On websites like eBay, which has a vast presence globally, consumers are able to buy a wide array of products at auction or through fixed-price arrangements. According to figures, eBay transactions are more profitable for sellers as compared to most consignment stores. This reduces the concerns about the disposal of excess clothing as most garments offered for sale at eBay end up being purchased, are limited. Shopping from home for gently used or pre-owned quality garments gives the customers, access to designer items that may not even be available in their city (Parker \& Webera, 2013).

"Although, import of second hand clothing is prohibited in India, import of woollen fibres is permitted, among which are "mutilated hosiery," a trade term for wool garments shredded by machines in the West prior to export. India is considered a large domestic market for second hand clothing for recycling after donating to servants or others. Here, the materiality of cloth itself serves as a strategic resource for the unmaking and remaking of persons and identities" ( Hansen 2004).

"According to Amarjit Singh Batra, CEO, OLX India, In 2014, size of used goods market in urban India was Rs 22,000 crore.. According to the online players, pre-owned are not only for the poor (Afaqs, 2015). According to statistics from Alibaba.com, one of the leading business-to-business trading platforms in the world, online demand for second-hand products in India saw a triple-digit annual growth in November 2009, when the global recession was at its peak. "But despite the moderate recovery in the global economy, Indian suppliers are still seeing a significant level of interest in pre-owned products from international buyers, especially in used clothes and used cars" says Sandeep Deshpande, country general manager, Alibaba.com (Poduwal \& Mehra, 2011). Traditional and settled websites like eBay and new players like Olx and Quikr have extensive ad campaigns and foreign investments that are providing suitable platform for selling and buying second hand.. Vogue initiated organizing an event which gave a chance to buy deeply discounted designer handbags donated by prominent women at Fashion's Night Out. The event attracted long lines of well-dressed fashionistas at a Delhi mall and the money raised went to charity (Dsouza, 2014).

A similar initiative in Mumbai, Back Alley's Thrift Shop, started by cousins Radhika Dhawan and Maya Goyal, also raises money for NGOs. Their first one-day sale, held in June 2013 at Ave 29 in Hughes Road, sold around 150 books, 500 pairs of shoes and 200 items of clothing, and raised Rs 1.5 lakh.( Chaturvedi, 2014)

According to research the biggest concern of people while buying second hand clothes is the level of hygiene (Dsouza, 2014, Parker \& Webera, 2013). This has given rise to questions surrounding their origin being raised in the first place. People who are not interested to buy used-goods asserted that they are never too sure of who had been using them. But for the regular customers, it is highly necessary that the clothes be washed thoroughly even if they still smell fresh from the disinfection process (Noon, 2011). 
Shillong city in India has long been associated as the fashion capital of the North East. It is a well-known second hand clothes hub. Even after the fact that there are several questions being raised on the health and hygiene concerns of second hand clothing all over the country, the market is generating considerable amounts of profits. There is a surge in number of branded cloths shops in the city, the popularity of this second hand market has not been affected at all. Some shop-keepers claimed that they have customers from all walks of life, including senior officials and from well - off families, picking their favourite garment. Students and youths in general are the main patrons to these stores, owing to their tight resources and their yearning for undemanding fashion.( Meghalaya Times, 2014)

\subsection{Consumption Intention of used Clothing}

Due to the advancement of technology, the people have a great opportunity in buying and selling online. Although there are traditional markers for the second-hand products. The uses of social networks and smartphones have also revolutionized the second-hand product market among all classes of people in society. Therefore, it is important to pay attention to the factors that affect the purchase of second -hand products as second-hand products consumption is increasing every day. Very little research focused on second hand garments as it is an essential to know the psychology of the consumers about the factors that determine the acquiring secondhand apparel. For example, Gorang, and Hand (1984) determined that the physical closeness of the clothing is related with the willingness to buy second-hand clothing to the body and that the closer the garment is to the body (such as sleepwear, underwear, and footwear), the less willing consumers are to purchase the garment. O'Reilly et al..

\subsection{Purchase Intention}

Purchase intention is a kind of decision-making in purchasing the particular brand (Shah et al., 2012). Morinez et al. (2007) define purchase intention as a situation where consumer tends to buy a certain product in certain condition.

Customers purchase decision is a complex process. Purchase intention usually is related to the behaviour, perceptions and attitudes of consumers. Purchase behaviour is a key point for consumers to access and evaluate the specific product. Gosh (1990) states that purchase intention is an effective tool to predict buying process. Under the influence of price or perceived quality and value, purchase intention may be changed. In addition, consumers are affected by internal or external motivations during the buying process (Gogoi, 2013). Researchers have defined six stages before deciding to buy the product, which are: awareness, knowledge, interest, preference, persuasion and purchase (Kotler \& Armstrong, 2010) (Kawa et al., 2013). Customers always think that products which is provided at low cost so quality cannot be trusted (Gogoi, 2013).

Most of previous studies has explained the significant relationship of brand with the consumers' purchase intention (Arslan \& Altuna, 2010; chi et al., 2008; Tariqet al., 2013). Zeeshan (2013) in his study found that brand image has influenced male to purchase of products. Divolf (2005) states that there is more likely that high brand awareness lead to high brand association in the minds of customers.

Subsequently there is a need for research that focuses on consumers' willingness to purchase second hand and what are the factors stopping them. This is the knowledge gap this exploratory study aims to fill. 


\section{RESEARCH METHODOLOGY}

\subsection{Hypothesis Development}

Measurement items were developed by adapting some of the items from the literature. A pool of items was created and sentence completion technique was used to form the questions. To eliminate and discover potential problems in this study, a pilot test and pre-test of the questionnaire were conducted. The pilot test was conducted using 30 graduate students and women to assess the questionnaire's logical ease of understanding, consistencies, contextual relevance and sequence of items so to enable it to be refined. The resulting questionnaire consisted of 24 items to be studied. In addition, the comments also led to several minor modifications of the wording. Scale's items were measured using five-Point Likert-type scales ranging from (1) Least important to (5) Most important. These 24 variables lead to formation of 5 factors. This was done with the help of SPSS. Table 1 shows the formation of 5 factors. Given the preceding discussion, the following hypotheses are proposed:

H1: There is a significant association of functionality and purchase intention of second hand clothing.

$\mathrm{H} 2$ : There is a significant association of convenience and purchase intention of second hand clothing.

Table 1: Results of the exploratory factor analysis

\begin{tabular}{|c|c|c|c|}
\hline Factor & Measurement item & $\begin{array}{l}\text { Factor } \\
\text { loading }\end{array}$ & $\alpha$ \\
\hline \multirow{5}{*}{ Functionality } & If the clothes are in fashion & 0.882 & \multirow{5}{*}{0.907} \\
\hline & If My size and choice would not be available & 0.857 & \\
\hline & If there is more variety & 0.805 & \\
\hline & If the condition of clothing is good & 0.774 & \\
\hline & $\begin{array}{l}\text { I will be ok purchasing garments that do not fall next to } \\
\text { my skin }\end{array}$ & 0.771 & \\
\hline \multirow[t]{6}{*}{ Convenience } & If the shop is not crowded, unorganized and poorly lit & 0.814 & \multirow[t]{6}{*}{0.865} \\
\hline & If I have a close proximity & 0.782 & \\
\hline & If the shopping atmosphere is good & 0.762 & \\
\hline & Shopping online would be more convenient & 0.745 & \\
\hline & $\begin{array}{l}\text { If the garments are well displayed and shop ambience is } \\
\text { good }\end{array}$ & 0.682 & \\
\hline & If I find something rare which is not available easily & 0.613 & \\
\hline \multirow[t]{4}{*}{ Perceived Hygiene } & If the garments look as good as new & 0.872 & \multirow[t]{4}{*}{0.873} \\
\hline & If I am assured that the garments are dry cleaned & 0.845 & \\
\hline & I the clothes are not dirty and smelly & 0.711 & \\
\hline & If I am sure about the hygiene of the product & 0.710 & \\
\hline \multirow[t]{7}{*}{ Personal attitude } & I don't feel good, associate it with low self esteem & 0.805 & \multirow[t]{7}{*}{0.785} \\
\hline & Not ready to buy of somebody I don't know & 0.762 & \\
\hline & Owning second hand clothes is weird & 0.717 & \\
\hline & I feel Creepy about buying pre-owned clothes & 0.712 & \\
\hline & It is meant for lower income & 0.711 & \\
\hline & I will try if it is proved that it is good for the environment & 0.644 & \\
\hline & I will wear if nobody knows it is pre owned & 0.610 & \\
\hline \multirow[t]{3}{*}{ Social Factor } & $\begin{array}{l}\text { I will be embarrassed to be seen in an exchange/ second } \\
\text { hand sale event }\end{array}$ & 0.783 & \multirow[t]{3}{*}{0.698} \\
\hline & $\begin{array}{l}\text { My family members' have negative attitudes about } \\
\text { second-hand apparel }\end{array}$ & 0.682 & \\
\hline & My friends would be judgmental of second-hand clothing & 0.675 & \\
\hline
\end{tabular}


H3: There is a significant association of perceived hygiene and purchase intention of second hand clothing.

$\mathrm{H} 4$ : There is a significant association of personal attitude and purchase intention of second hand clothing.

H5: There is a significant association of social factor and purchase intention of second hand clothing.

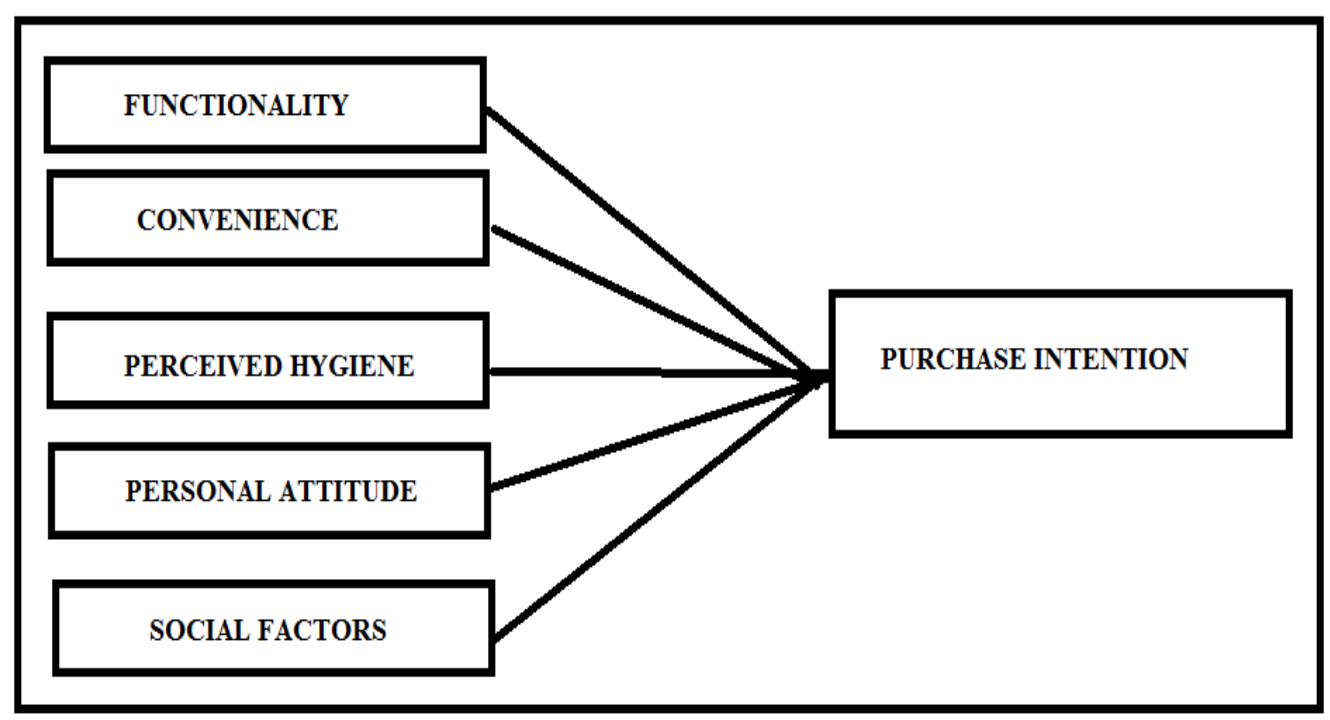

Figure 3: Research framework

\subsection{Research Design}

This research is a quantitative research where sources of information are gathered from questionnaire. Through the self-administered and closed-ended questionnaire having matrix questions. This study is descriptive. In this study probability sampling was used. From female students from NCR, data was collected. According to socio economic classification, the study included uppermost and part of the middle segment according to SEC, 2013. The segment covered would the group from A1 to B1. The segment is described as the people who owns at least 5 consumer durable items and have at least went to some college (including a diploma). The study studied only females. The reason for which is that the experiments were in communities where there are more women and secondly, women would be more willing to fill questionnaire about shopping and consumption as compared to men (Birtwistle and Moore, 2008).The population estimated was 500. Out of the total population, 150 respondents responded to the research survey.

\subsection{Data Analysis}

To analyse the questionnaire SPSS 17.0 was applied. The techniques of analysis used in this study were descriptive (mean, standard deviation) and inferential analysis (regression) to sum up the data collected. In order to describe the sample characteristics in the data analysis report, demographic data such as age, income, place of living and education level are included in the questionnaire. These data are structured in a range of response option, rather than seeking exact figures.

\section{RESULTS AND DISCUSSION}

This section presents the findings of this study. The data are interpreted using the mean, factor analysis and regression methods of SPSS. 


\subsection{Reliability and Validity Analysis}

Before testing the individual variables, validity of the questionnaire was checked by descriptive analysis where Kaiser-Meyer-Olkin measure of sampling adequacy (KMO) (table 3) value came out to be .927 . Researchers suggest that for the questionnaire to be valid, KMO value should be more than .50. Also the result of Bartlett's test showed positive significance. Hence the validity of the questionnaire was established.

Validity was also examined in terms of discriminant validity. Discriminant validity assesses whether individual indicators can adequately distinguish between different constructs. Variables were considered to have adequate discriminant validity if the square root of the average variance extracted (AVE) for a construct is higher than the variance shared between the construct and other constructs in the table.

The correlation of the variables was measured on the anti-image correlation matrix. The diagonals on the ant-image matrix had value more than .88 which is considered to be good by the researchers. This implies that all variables have sufficient correlation with the other variables and the questionnaire is reasonably accurate. All the above results gave a positive indication of measures of sampling adequacy.

Reliability was evaluated using Cronbach's alpha. Cronbach reliability coefficients were all higher than the minimum cut off score of 0.70 (table 1). All composite reliability coefficients were greater than 0.7, indicating adequate internal consistency (Fornell and Larcker 1981). The research also considered the guidelines recommended by Hair et al. (2006) in determining the relative importance and significance of the factor loading of each item, (i.e., loadings greater than 0.30 are considered significant; loadings greater than 0.40 are considered important; and loadings which is more than 0.50 or greater considered a significant). The items for each construct loaded were well below the standard maximum cut off of .55 .

\subsection{Demographic Profile}

Table 2: Sample Characteristics $(\mathrm{n}=160)$

\begin{tabular}{|l|l|c|c|}
\hline \multicolumn{1}{|c|}{ MEASURE } & \multicolumn{1}{|c|}{ ITEM } & FREQUENCY & PERCENTAGE \\
\hline \multirow{2}{*}{ Age } & $18-24$ & 119 & 74 \\
\cline { 2 - 4 } & $24-35$ & 41 & 26 \\
\hline \multirow{3}{*}{ Location } & New Delhi & 111 & 69 \\
\cline { 2 - 4 } & NCR & 49 & 31 \\
\hline \multirow{5}{*}{ Income } & Less than Rs. 50,000 & 55 & 34 \\
\cline { 2 - 4 } & $\begin{array}{l}\text { More than Rs. 50,000 - Rs. 1 } \\
\text { Lakh }\end{array}$ & 44 & 28 \\
\cline { 2 - 4 } & $\begin{array}{l}\text { More than Rs. 1 Lakh - Rs. 2 } \\
\text { Lakh }\end{array}$ & 60 & 38 \\
\hline \multirow{2}{*}{ Occupation } & Working & 78 & 49 \\
\cline { 2 - 4 } & Students & 82 & 51 \\
\hline
\end{tabular}

Table 3: KMO and Bartlett's Test

\begin{tabular}{|l|l|l|}
\hline \multicolumn{2}{|l|}{$\begin{array}{l}\text { Kaiser-Meyer-Olkin Measure of Sampling } \\
\text { Adequacy. }\end{array}$} & .927 \\
\hline \multirow{3}{*}{$\begin{array}{l}\text { Bartlett's Test } \\
\text { of Sphericity }\end{array}$} & Approx. Chi-Square & 1131.380 \\
\cline { 2 - 3 } & df & 435 \\
\cline { 2 - 3 } & Sig. & .000 \\
\hline
\end{tabular}




\subsection{Regression Analysis}

Table 4 shows the R-Square and Durbin-Watson test. R-Square test result of 0.507 can be accepted for the regression analysis. The Durbin-Watson test result of 1.816, an indicator that the autocorrelation is almost reaching to zero or there is a significant difference which exists between the dependent and independent variables (no autocorrelation). From the ANOVA in table 5, it appears that the three predictor variables are not all equal to each other and could be used to predict the dependent variable, purchase intention as is indicated by $\mathrm{F}$ value of 16.873 and strong significance level of $0.000(\mathrm{p}<0.05)$. Further as shows in table 6 , the results show that out of five factors, three factors i.e functionality, convenience, perceived hygiene have a significant $(\mathrm{p}<0.05)$ influence towards purchase intention with high Beta 0.207, 0.366 and 0.431 respectively. However, personal attitude and social factor are less significant impact $(\mathrm{p}>0.05)$ with low Beta of -.005 and .092 respectively. The VIF value of less than 10 for all variables show that the problem of multi-collinearly have not existed and all data are mutually exclusive. As for the interpretation, the test indicates that functionality, convenience and perceived hygiene have significant influence towards customer purchase intention of second hand apparel. By examining the $t$ statistic for all the independent variables it has apparently confirmed that functionality, convenience and perceived hygiene have significant relationship due to strong significant level $(\mathrm{p}<0.05)$ with purchase intention, indicating that the null hypotheses for $\mathrm{H} 1$, $\mathrm{H} 2$ and $\mathrm{H} 3$ can be rejected. On the other hand, the null hypotheses for H4 and H5 which represented personal attitude and social factor are correct and can be accepted.

Table 4: R square and Durbin-Watson Test

\begin{tabular}{|c|c|c|}
\hline Model & R Square & Durbin-Watson \\
\hline 1 & 0.507 & 1.816 \\
\hline
\end{tabular}

Table 5: Annova test

\begin{tabular}{|c|c|c|}
\hline Model & F & Sig \\
\hline 1 & 16.873 & 0.000 \\
\hline
\end{tabular}

Table 6: Result of Coefficients

\begin{tabular}{|l|c|c|c|c|c|}
\hline \multicolumn{1}{|c|}{ Variable } & Standardized & Coefficients & & \multicolumn{2}{c|}{ Collinearity Statistics } \\
\hline & Beta & $\mathrm{t}$ & sig. & Tolerance & VIF \\
\hline 1 (constant) & & 0.298 & 0.764 & & \\
\hline Functionality & 0.207 & 2.516 & 0.017 & 0.673 & 1.49 \\
\hline Convenience & 0.366 & 4.532 & 0.009 & 0.892 & 1.113 \\
\hline Perceived Hygiene & 0.431 & 5.916 & 0.001 & 0.753 & 1.446 \\
\hline Personal Attitude & -0.005 & -0.81 & 0.936 & 0.698 & 1.428 \\
\hline Social Factor & 0.092 & 1.472 & 0.412 & 0.97 & 1.028 \\
\hline
\end{tabular}

\section{DISCUSSION}

The statistical results show that Indian consumers place relatively high level of importance on functionality, convenience and hygiene whereas low level of importance attitudinal factors like personal and societal factors in their intention to purchase second hand clothing.

Consumers in the modern society are well informed about the hygiene issues and sustainable factors through their own initiative and reading from newspapers, books, magazines and etc. With the recent explosion of information technologies, consumers have ready access to plenty of information of the places where they can buy second hand clothing. It is true that 
fit, quality, trend and condition of the garments are the most critical conditions that the garment is worth buying. Sustainability as the main aim for buying second hand apparel holds true for negligible population in India. Many consumers believe that they get a new garment in the price at which second hand garment is sold but at the same time they are comfortable wearing the garment which does not fall directly on the skin.

Factors that were found to have significant impact towards the customer purchase intention of second hand clothing are convenience and perceived hygiene. Perceived hygiene is not all about cleanliness alone. Shopping atmosphere of the places also is a huge determinant. Second hand clothing is now portrayed in the mass media or through national and NGO's advertising efforts (sustainable fashion) as the best option for dressing up without hurting the planet. Besides that, second hand garments are known for their rare and vintage finds. When these values have been communicated effectively, the consumers will develop positive impression which eventually could turn into the purchase and satisfaction towards the product.

\section{CONCLUSION}

The rapid increase of clothing consumption over the recent decades has contributed significantly on increasing the burden on environment as a result of; the high consumption of natural resources and land; increasing amounts of carbon emissions; excessive use of toxic chemicals; polluting air, land and water; and increasing amounts of waste. Adopting and encouraging more circular economies is a part of the European commission's strategy to achieve sustainable consumption of resources and protection for environment. The purpose of this Research was to study the possibilities for improving the practice of second hand clothes consumption. In order to achieve the purpose of the study, relevant literatures have been studied in order to build conceptual framework and learn the results of previous studies.

The main conclusion in this study is that dealing with the challenges that the second hand market requires collective actions from and cooperation between all involved parties in this value chain, including businesses of second hand clothes, contributors and consumers of used clothes, governmental authorities, municipalities, politicians and private sector.

Retailers should respond to the demand in the extending the life of garments and use this opportunity, so consumers are able to pass them on to the community without having them end in landfill (Wallander, 2012). One of the biggest reasons as to why consumers used to shop for second-hand items was due to its low cost (Pilon, 2015); however, as a sustainable way of consumption that might be changing as consumers today view second- hand purchasing is worthy of further study.

\section{REFERENCES}

[1] Afaqs!, New Delhi, in Digital, February 23, 2015, Urban households hoard Rs 56, 200 crore worth of unused goods: OLX CRUST Survey

[2] Allwood, J., Laursen, S., de Rodriguez, C., \& Bocken, N. (2006). Well dressed? The present and future sustainability of clothing and textiles in the United Kingdom. Institute for Manufacturing, University of Cambridge. [Online] Available from http://www.ifm.eng.cam.ac.uk. [Accessed: $1^{\text {st }}$ September 2019].

[3] Berg Encyclopedia of World Dress and Fashion > Volume 10 - Global Perspectives > Part 4 : Fashion Worldwide, Secondhand Clothing, Author: Karen Hansen and Tranberg, DOI: http://dx.doi.org/10.2752/BEWDF/EDch10032, 2011

[4] Chaturvedi, P., User-friendly. Some of these fashionstas are trying to make a business out of recycled clothes, 22 November 2015, Live Mint E Paper, [Online], Available at 
http://www.livemint.com/Leisure/ve0e2XpuFm0qRA8DUd32wI/Userfriendly.html, Accessed 2 October

[5] Chi, H. K., Yeh, H. R., \& Huang, M. W. (2009). The Influences of advertising endorser, brand image, brand equity, price promotion on purchase intention: The mediating effect of advertising endorser. The Journal of Global Business Management, 5(1), 224-233.

[6] Dsouza M., When second hand buy is actually first rate, Hindustan Times, Updated: Mar 02, 2014 09:12 IST, [Online] available at http://www.hindustantimes.com/brunchstories/when-second-hand-buy-is-actually-first-

rate/article12015.1189448.aspx?li_source=LI\&li_medium=dontmiss\&li_campaign=related-test, Accessed 14 September2018,

[7] Gogoi, B. J. (2013). Study of antecedents of purchase intention and its effect on brand loyalty of private label brand of apparel. International Journal of Sales \& Marketing, 3(2), 73-86.

[8] Gregson, N., \& Crewe, L. (2003). Second-hand Cultures.New York, NY: Berg.

[9] Guiot, D., \& Roux, D. (2010). A second-hand shoppers' motivation scale: Antecedents, consequences, and implications for retailers. Journal of Retailing, 86(4), 355-371.

[10] Gupta, V., \& Khare, A. (2011). Value Creation in post-consumer apparel waste: a study of urban-rural dynamics in India, [Online] Available from. http://process.arts.ac.uk/sites/default/files/varsha-gupta.pdf [Accessed: 30th August 2015].

[11] INDIA, MINISTRY OF TEXTILES. (2013) Textiles committee, Government of India, , annual report 2011-2012, Mumbai, [Online] Available from: http://textilescommittee.nic.in/writereaddata/files/documents_reports/AR_2011_12.pdf [Accessed: 02th September 2018].

[12] Kaushik, N., Husband wife duo start up Tete-a-Rent Makes Fashion Resale \& Rental Very Easy, July 10, 2015, http://indianbizparty.com/startup-stories/tete-a-rent

[13] Kawa, L. W., Rahmadiani, S. F., \& Kumar, S. (2013). Factors affecting consumer decisionmaking: a survey of young-adults on imported cosmetics in Jabodetabek, Indonesia. SIJ Transactions on Industrial, Financial \& Business Management, 1(5), 175-180.

[14] Kotler, P., \& Armstrong, G. (2010). Principles of marketing. Pearson education.

[15] Lofholm, N. (2007, October 28). Old clothesline is still hanging tough, Humble clotheslines' simplicity blows past technology in energy-conscious era. Denver Post, [Online] Available from: http://www.denverpost.com/ci_7301548. [Accessed: $1^{\text {st }}$ September 2018]

[16] Markova, I., \& Bayanduuren, N. (2017). Conscious consumption: consumer attitudes and behaviors toward second-hand shopping conscious consumption: consumer attitudes and behaviors toward second-hand shopping.

[17] McAfee, A., Dessain, V., \& Sjöman, A. (2004). Zara: IT for fast fashion. Harvard Business School.

[18] Majaw, D, Second hand clothes: Shillong's fashion pool, Written by Meghalaya Times. Posted in Front Page, [Online], available at http://meghalayatimes.info/index.php/frontpage/19738-second-hand-clothes-shillong-s-fashion-pool. Accessed: 15 October 2018. 
[19] Müge Arslan, F., \& Korkut Altuna, O. (2010). The effect of brand extensions on product brand image. Journal of Product \& Brand Management, 19(3), 170-180.

[20] Muhammad Zeeshan, Z. (2013). The Impact Of Mobile Service Attributes On Males' and Females'purchase Decision. Management \& Marketing, 8(4).

[21] Noon, D. J. (2011). Changing patterns of consumerism: the rise and rise of the second hand: a thesis presented in partial fulfilment of the requirements for the degree of Master of Arts in Visual and Material Culture at Massey University, Wellington, New Zealand (Doctoral dissertation).

[22] O’Reilly, L., Rucker, M., Hughes, R., Gorang, M., \& Hand, S. (1984). The relationship of psychological and situational variables to usage of a second-order marketing system. Journal of the Academy of Marketing Science, 12(3), 53-76.

[23] Palmer, A. (2005). Vintage whores and vintage virgins: Second hand fashion in the twentyfirst century. Old clothes, new looks: Second hand fashion. Oxford: Berg.

[24] Parker, B., \& Weber, R. (2013). Second-hand spaces: restructuring retail geographies in an era of e-commerce. Urban Geography, 34(8), 1096-1118.

[25] Pilon, A (2015, August 25). Second hand shopping survey, Goodwill named top secondhand store. December 7, 2018 from https://aytm.com/blog/daily-survey-results/secondhand

[26] Poduwal S. \& Mehra M, The story of India's Rs 60,000 cr second-hand market, minus cars and bikes, ET Bureau Oct 30, 2011 [ online] available at http://articles.economictimes.indiatimes.com/2011-10-30/news/30336718_1_secondhand-market-incomes-product-cycles/2, Accessed 22 September 2015.

[27] Rodgers, L., Where do your old clothes go?, BBC News, 11 February 2015

[28] Shah, S. S. H., Aziz, J., Jaffari, A. R., Waris, S., Ejaz, W., Fatima, M., \& Sherazi, S. K. (2012). The impact of brands on consumer purchase intentions. Asian Journal of Business Management, 4(2), 105-110.

[29] Steinbring, Y., \& Rucker, M. (2003). Utilization of post-consumer textiles and clothing. Journal of Family and Consumer Sciences, 95(2), 33.

[30] Stroeker, N. E. (1995). Second-hand markets for consumer durables. Thesis Publishers.

[31] Tariq, M. I., Nawaz, M. R., Nawaz, M. M., \& Butt, H. A. (2013). Customer perceptions about branding and purchase intention: a study of FMCG in an emerging market. Journal of Basic and Applied Scientific Research, 3(2), 340-347.

[32] Van Damme, I., \& Vermoesen, R. (2009). Second-hand consumption as a way of life: public auctions in the surroundings of Alost in the late eighteenth century. Continuity and change, 24(2), 275-305.

[33] Wallander, M. (2012). Why textile waste should be banned from landfills. Retrieved October, 5, 2013.

[34] Williams, C. C., \& Paddock, C. (2003). The meanings of informal and second-hand retail channels: Some evidence from Leicester. The International Review of Retail, Distribution and Consumer Research, 13(3), 317-336. 
[35] Younus, S., Rasheed, F., \& Zia, A. (2015). Identifying the Factors Affecting Customer Purchase Intention. Global Journal of Management and Business Research.

[36] Kate Fletcher, Sustainable Fashion \& Textiles p.8 \& Matilda Lee Eco Chic, p.77

[37] Quote, University of Cambridge Institute for Manufacturing, Well dressed?, P.2

[38] University of Cambridge Institute for Manufacturing, Well dressed?, p.45 \& Kate Fletcher, Sustainable Fashion \& Textiles, p.9

[39] Matilda Lee, Eco Chic, p.84

[40] Kate Fletcher, Sustainable Fashion \& Textiles, p.50 \& Matilda Lee, Eco Chic, p.89

[41] Quote, Matilda Lee, Eco Chic p.89 